\title{
New records of plant parasiticAsterinaceae (Dothideomycetes, Ascomycota) with intercalary appressoria from Central America and Panama
}

\author{
Tina Antje Hofmann ${ }^{1} \&$ Meike Piepenbring ${ }^{2}$
}

${ }^{1}$ Herbarium UCH, Mycological Research Center (CIMi), Autonomous University of Chiriquí (UNACHI), 0427, David, Chiriquí Province, Panama; ${ }^{2}$ Institute for Ecology and Evolution, Cluster for Integrative Fungal Research (IPF), Goethe University, Max-von-Laue-Str. 13, 60438 Frankfurt am Main, Germany

Author for correspondence: Tina Antje Hofmann, e-mail: hofmann_tina@gmx.de

\begin{abstract}
New records of species of Asterinaceae with intercalary appressoria infecting plants in Central America and Panama are described and illustrated in detail. New records are Asterolibertia licaniicola on the new host Licania arborea (Chrysobalanaceae), Asterolibertia nodulosa on the new hosts Oxandra venezuelana and Xylopia sp. (Annonaceae), and Cirsosia splendida on the new hosts Chrysobalanus icaco and Hirtella triandra (Chrysobalanaceae). The teleomorph C. splendida is linked for the first time to the asexual morph Homalopeltis chrysobalani based on morphological observation. For the presented fungi an identification key is provided and infection strategies are discussed. Nomenclatural novelties are introduced, Leprieuria radiata becomes a synonym of $H$. chrysobalani and Asterina nodulifera is recombined into Asterolibertia nodulifera.
\end{abstract}

Key words: Asterolibertia, Chrysobalanus icaco, Cirsosia, Homalopeltis, obligate biotrophs.

\section{INTRODUCTION}

Species of Asterinaceae (Dothideomycetes, Ascomycota) are parasitic microfungi of vascular plants in the tropics and subtropics. An overview of the family is provided by Hofmann et al. (2010). Asterinaceae infect mostly wild plants but also have been reported from cultivated crops such as Asterina manihotis Syd. on Manihot esculenta Crantz (Hofmann \& Piepenbring, 2008). Due to their obligate biotrophic lifestyle these fungi depend on a living host, but they do not cause visible diseases. However, they can have negative effects on the photosynthesis of the plant and/or weaken host defense. Asterina congesta Cooke was shown to influence photosynthetic activity on sandal tree (Santalum album L.) in India since the extensively growing black colonies prevent the entry of light and reduce the chlorophyll content in leaves (Hosagoudar et al., 1997). It was shown that $A$. congesta infection in sandal tree leads to increased production of cyclic compounds such as proline, indicating high stress levels in the host (Hosagoudar et al., 1997). The accumulation of proline in plants is known as a common physiological response to environmental abiotic and biotic stresses (Verbruggen \& Hermans, 2008).

According to Hansford (1946), the family includes specialized ecto-parasites with surface mycelia that feed via haustoria on individual epidermal cells of a particular host. In the modified family concept characteristics such as spherical asci and their vertical development in the shield-shaped ascomata (thyriothecia) are prioritized upon infection strategy (Müller \& Arx, 1962). Accordingly, species of Asterinaceae sensu Müller \& Arx (1962) show various modes of host infection, like haustoria in single epidermal cells, hyphal penetration of stomata, intraand subcuticular hyphae or stromata, intracellular or intercellular hyphae, or hypostromata in epidermal and subepidermal cells. Depending on the species, infection types can occur separately or combined. Due to the lack of detailed molecular studies, it is unknown whether infection strategies might represent informative characteristics for the separation of species and genera in this family.

Species of Asterina Lév. (Aina.), Asterolibertia G. Arnaud (A.), Cirsosia G. Arnaud, Lembosia Lév., or Trichasterina G. Arnaud typically form lateral or intercalary mycelial appressoria for the infection of host tissue. Surface mycelia of species of Asterolibertia and Cirsosia have intercalary appressoria at regular intervals. These appressoria are often inflated and, therefore, can be distinguished easily from cells of the surface mycelium. However, some species develop intercalary appressoria that are identical to other mycelial cells and can only be distinguished by an indistinct penetration porus. In these cases it is useful to study thin transversal sections of fresh leaves with fungal infection. The haustoria can be easily recognized especially when stained with cotton blue, and are normally localized directly below the appressoria. 
Species of Asterolibertia form circular ascomata, whereas Cirsosia species are characterized by elongated, L-, Y- or $\mathrm{X}$-shaped ascomata.

In this study two species of Asterolibertia and one species Cirsosia and the asexual stage Homalopeltis are reported for Central America and Panama for the first time and are described and illustrated in detail. The teleomorph $C$. splendida is linked for the first time to the asexual morph $H$. chrysobalani based on morphological observation. Additionally, an identification key of genera of Asterinaceae with intercalary appressoria from western Panama is provided and nomenclatural novelties are introduced.

\section{MATERIALS AND METHODS}

Infected leaves with colonies of Asterolibertia and Cirsosia were collected randomly in different habitats in western Panama between 2003 and 2007. Host plants were identified with the Flora of Panama (Woodson \& Schery, 1943-1980). Air-dried material was observed with a Nikon SMZ645 stereomicroscope and a Nikon Eclipse 80i microscope with drawing tube. Microscopic slides, drawings and materials used for scanning microscopy (SEM) were prepared according to Hofmann et al. (2010). Type material was loaned from the US National Fungus Collections, Beltsville, Maryland (BPI) and the Plant Protection Research Institute, Pretoria (PREM). Known host plants and the distribution of the presented species were taken from the Fungal Databases (Farr \& Rossman, 2010; Systematic Mycology and Microbiology Laboratory, ARS, USDA, retrieved February 23, 2014, from http://nt.ars-grin.gov/ fungaldatabases/) and examined herbarium specimens. Dried herbarium specimens were deposited in the Forschungsinstitut Senckenberg, Frankfurt (FR), in the Botanische Staatssammlung München (M), Germany, and in the Herbario Nacional de la Universidad de Panamá, Panama (PMA).

\section{RESULTS}

Key to species of Asterinaceae with intercalary appressoria in western Panama

1 Sporomata elongated, on Chrysobalanaceae Cirsosia splendida 1* Sporomata circular, on Chrysobalanaceae or Annonaceae

2 Asexual, pycnothyria with pores, conidia cylindrical .. Homalopeltis chrysobalani

2* Teleomorphic, thyriothecia with star-shaped fissures, ascospores ellipsoidal .. 3

3 Internal hypostroma missing, haustoria present ............ .............................................. Asterolibertia licaniicola $3^{*}$ Internal hypostroma present, spread in epidermal layer Asterolibertia nodulosa

\section{New records for Central America and Panama}

With this study the number of known species of Asterinaceae from Panama increases from 26 to 29. The genera Asterolibertia and Cirsosia/Homalopeltis are reported for the first time for Panama.

\section{Asterolibertia licaniicola Hansf., Proc. Linn. Soc. London 160:140 (1949). Figures 1, 4A.}

Type on Licania sp. (Chrysobalanaceae). Brazil, Santa Catarina, São Francisco, June 1885, E. Ule, Rabenhorst-Winter 3746 (type, PREM 4086!, labeled as Asterina inaequalis).

Colonies epiphyllous, irregularly circular, mostly single, sometimes confluent, $0.1-22 \mathrm{~mm}$ diam. $(\mathrm{n}=10)$, black, conspicuous, and dense. Surface hyphae straight, rigid, not undulating, branching mostly opposite, rarely

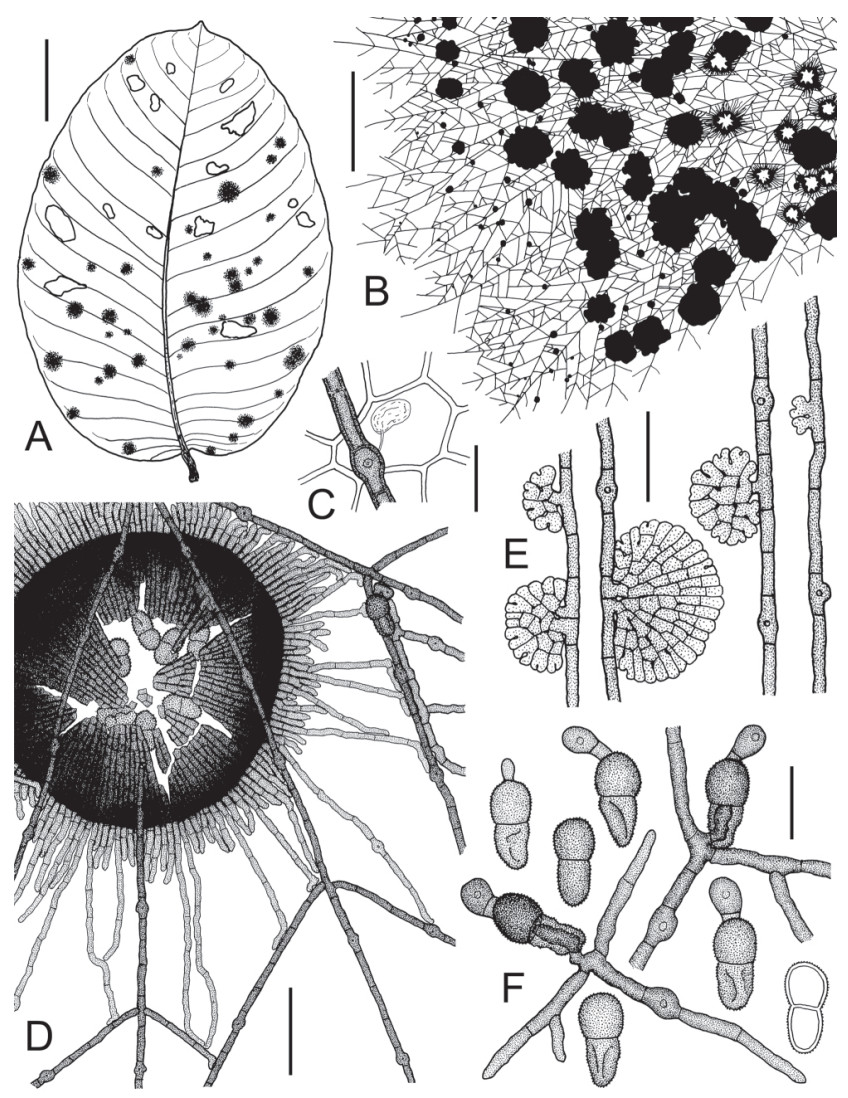

FIGURE 1- Asterolibertia licaniicola on Licania arborea (T.A. Hofmann 578). A. Adaxial side of infected leaf. Scale bar $=4 \mathrm{~cm}$; B. Part of the colony with large immature and smaller mature thyriothecia and surface mycelium. Scale bar $=1 \mathrm{~mm} ; \mathbf{C}$. Haustorium in epidermal host cell. Scale bar $=15 \mu \mathrm{m}$; D. Open thyriothecium with liberated, mature ascospores. Scale bar = $50 \mu \mathrm{m} ;$ E. Surface mycelium with intercalary appressoria and ascoma initials. Scale bar $=25 \mu \mathrm{m}$; F. Mature, slightly verrucose ascospores, some of them germinating. Lower cells of ascospores collapse during germination and endohyphae are formed. Scale bar $=20 \mu \mathrm{m}$. 
unilateral or alternate, brown, cells cylindrical, (9)15$28(34) \times(3.5) 4-4.5(5) \mu \mathrm{m}(\mathrm{n}=30)$, wall up to $1 \mu \mathrm{m}$ thick, smooth. Appressoria numerous, intercalary, cylindrical with a slightly swollen central part, (9)10-13(14) $\times(6) 7-8$ $\mu \mathrm{m}(\mathrm{n}=30)$, penetration pore central, up to $2.5 \mu \mathrm{m}$ diam. Haustoria arbuscular, globose, ellipsoidal to ovate or reniform, (10)11-14(15)×(5)6-8(9) $\mu \mathrm{m}(\mathrm{n}=10)$, hyaline, filling up to $1 / 4$ of host cell. Hypostroma absent. Thyriothecia single or confluent, circular, dimidiate, strongly fringed at margins, (200)217-302(350) $\times(310) 340-430(470) \mu \mathrm{m}$ diam. $(n=30)$, dark brown to black, opening with central starshaped fissures, young and closed ascomata conspicuously larger with entire margins. Scutellum radiate, composed of dichotomously branched filaments, cells isodiametric to cylindrical, straight, (4)6-12(17) $\times(3) 4-5(6) \mu \mathrm{m}(\mathrm{n}=30)$, dark brown to black. Asci globose to ovate, without ocular chambers, bitunicate, ascus wall $\mathrm{I}+, 37-40 \mu \mathrm{m}$ diam. $(\mathrm{n}=4)$, 8 -spored, rapidly disintegrating, developing on ascogenous hyphae with proliferating croziers, interascal tissue absent. Ascospores 2-celled, ellipsoidal, straight, septate, slightly constricted at septum, ends rounded, lower cell tapered, (25)26-29(30) $\mu \mathrm{m}$ long ( $\mathrm{n}=16)$, upper cell 12-15 $\mu \mathrm{m}$ wide, lower cell 11-13(14) $\mu \mathrm{m}$ wide, brown, wall up to $1 \mu \mathrm{m}$ thick, verrucose, germinating first at the distal part of the upper cell with a stalked and entire appressorium, lower cell collapsing during germination, with endohyphae. Anamorph absent.

Known host plants: Chrysobalanaceae: Licania arborea Seem. (new host plant) and Licania sp. (Hansford, 1949).

Known distribution: Neotropics: Central America (new record) - Panama (new record) and South America - Brazil (Hansford, 1949). A. licaniicola occurs in western Panama in lowland gallery forests at approx. $140 \mathrm{~m}$ a.s.l.

Specimens examined: BRAZIL. Santa Catarina: type, see above. PANAMA. Chiriquí Province: Los Algarrobos, border of Majagua river, ca. $140 \mathrm{~m}$ a.s.l., epiphyllous on Licania arborea (det. T.A. Hofmann) associated with Camarotella sp. (Phyllachorales, det. T. Trampe), 6 October 2007, T.A. Hofmann 578 (M-0141092, PMA); same locality, host species and associated organisms, 23 October 2007, T.A. Hofmann 597-A (FR, PMA).

Additional specimens examined: Asterolibertia inaequalis (Mont.) Toro. BRAZIL. Santa Catarina: São Francisco, on Licania sp., June 1885, E. Ule, RabenhorstWinter 3746 (type, BPI 689922, labeled as Asterina inaequalis). VENEZUELA. Bolívar: C203-204 km S. of El Dorado, on road between El Dorado and Sta. Elena, on unknown plant, 7 August 1972, K.P. Dumont, R.F. Cain, G.J. Samuels \& C. Blanco (BPI 690998).

Notes: The type collection of Asterolibertia licaniicola on Licania sp. contains various foliicolous thyriothecioid ascomycetes and the most dominant is Asterolibertia inaequalis (Mont.) Toro. In contrast to A. licaniicola, $A$. inaequalis forms conspicuous and dense colonies with a dark, rigid surface mycelium with barrel-shaped, intercalary appressoria, measuring 9-14 $\mu \mathrm{m}$ (Arnaud, 1925; Müller \& Arx, 1962). Asterolibertia inaequalis has 2-celled, dark brown, compressed ascospores with broadly rounded ends, with sizes of $32-40 \times 18-25 \mu \mathrm{m}$. The ascospores are smooth, with a septum in the upper third of the ascospore and germinate at the upper cell with a stalked, entire appressorium (Arnaud, 1925; Müller \& Arx, 1962). In contrast to $A$. inaequalis, the ascospores of $A$. licaniicola are smaller and finely verrucose (not observed by Hansford, 1949). During germination of the ascospore, a stalked, globose appressorium develops at the upper cell and an endohypha grows through the collapsed lower cell to initiate the development of surface mycelium (Figure 1F).

In Panama, A. licaniicola on Licania arborea forms large conspicuous colonies and is not associated with $A$. inaequalis. However, different fungal hyperparasites and mites were found on the colonies. A. licaniicola is illustrated here for the first time.

\section{Asterolibertia nodulosa (Speg.) Hansf., Proc. Linn. Soc. London 160:141 (1949). Figures 2, 3, 4B-D}

Type on Tabebuia sp. (Bignoniaceae) [= Guatteria sp. (Annonaceae) fide Theissen 1913]. Brazil, São Paulo, Apiahy, October 1881, no. 1585 (type, LPS n.v.).

$\equiv$ Asterina nodulosa Speg., Bol. Acad. Nac. Cien. Córdoba 11:563 (1889).

三 Asterina inaequalis var. nodulosa (Speg.) Theiss., Abh. Zool.-Bot. Ges. Wien 11:55 (1913).

Colonies epiphyllous, rarely hypophyllous, irregularly circular, single, $0.5-5 \mathrm{~mm}$ diam. $(\mathrm{n}=10)$, black, conspicuous and dense. Surface hyphae straight, rigid, not curved, branching opposite or rarely unilateral, brown to dark brown, at tips paler, septate, cells cylindrical, (10)19$31(33) \times(3.5) 4-5 \mu \mathrm{m}(\mathrm{n}=30)$, wall $0.5-1 \mu \mathrm{m}$ thick, smooth. Appressoria numerous, intercalary, cylindrical cell with a swollen middle part, (9)10-12(15) $\times(8) 10-12(14) \mu \mathrm{m}$ $(\mathrm{n}=70)$, penetration pore central, up to $1 \mu \mathrm{m}$ diam. Haustoria not observed, infection hyphae penetrate epidermal host cells. Hypostroma epidermal to subepidermal, composed of bundles of intracellular hyphae, hyaline to pale brown, completely filling epidermal host cells, infectious hyphae penetrating cuticle and form brown, thick-walled hyphae in the upper part of an epidermal cell from which a hyaline stroma is initiated, later brown, thick-walled hyphae develop in lower part of the epidermal cell to form infectious hyphae that penetrate subepidermal host cells. Thyriothecia crowded and confluent, circular, dimidiate, strongly fringed at margins, (200)259-317(350) $\mu \mathrm{m}$ diam. $(\mathrm{n}=64)$, dark brown to black, opening with central star-shaped fissures. Scutellum radiate, composed of dichotomously branched 


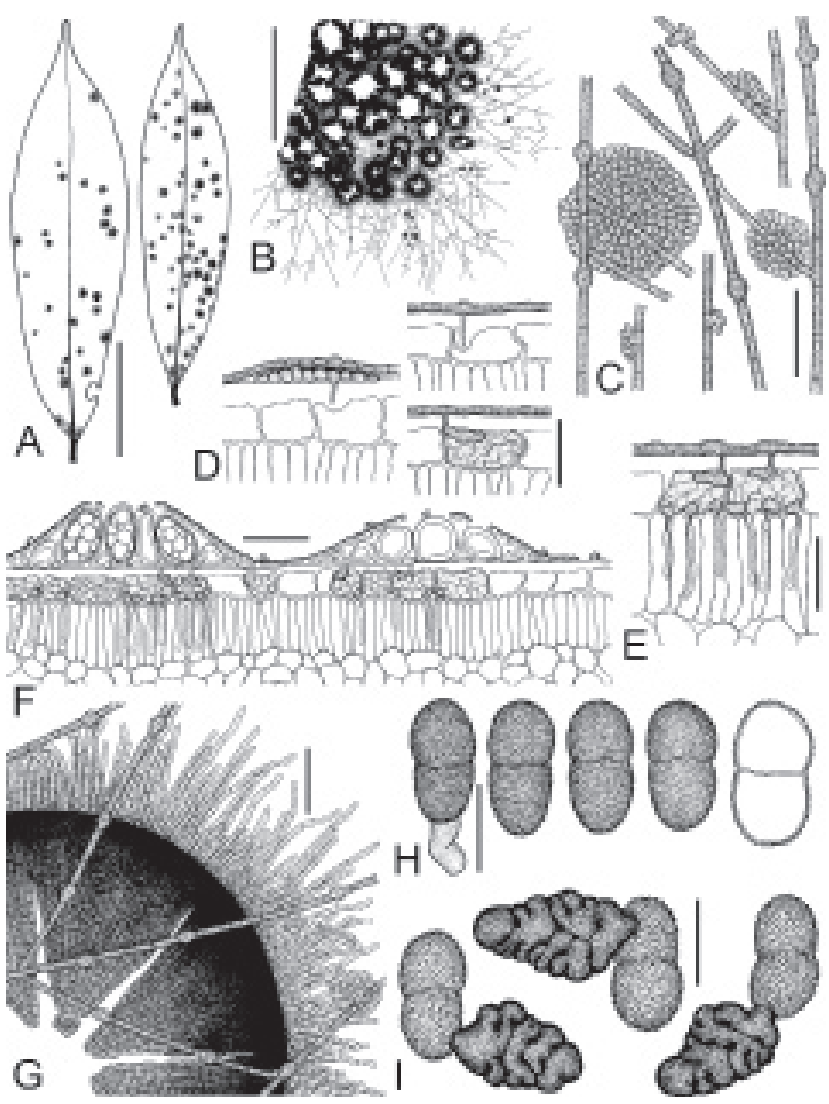

FIGURE 2 - Asterolibertia nodulosa on Oxandra venezuelana (T.A. Hofmann et al. 356). A. Adaxial side of infected leaves. Scale bar $=3 \mathrm{~cm}$; B. Part of the colony with confluent thyriothecia and surface mycelium. Scale bar $=1 \mathrm{~mm}$; C. Surface mycelium with intercalary appressoria and ascoma initials. Scale bar $=40$ $\mu \mathrm{m}$; D. Different stages of infection of host epidermis. Scale bar $=30 \mu \mathrm{m}$; E. Advanced infection of host epidermis with single hyphae penetrating the subepidermal layer. Scale bar $=30 \mu \mathrm{m}$; F. Cross section through a mature and immature thyriothecium and infected epidermis of the host. Scale bar $=50 \mu \mathrm{m}$; G. Open, immature thyriothecium. Scale bar $=50 \mu \mathrm{m} ; \mathbf{H}$. Mature, slightly verrucose ascospores, one of them germinating. Scale bar $=20 \mu \mathrm{m}$; I. Germinating ascospores, note lobate, multicellular appressoria. Scale bar $=20 \mu \mathrm{m}$.

filaments, cells isodiametric to cylindrical, straight, (4)5$12(17) \times(2) 3-5(6.5) \mu \mathrm{m}(\mathrm{n}=30)$, brown to dark brown or blackish. Asci globose to ovate, without ocular chambers, bitunicate, I-, (45)50-59(60.5) $\mu \mathrm{m}$ diam. ( $\mathrm{n}=30), 8$-spored, developing on ascogenous hyphae with proliferating croziers, rapidly disintegrating, interascal tissue present, filamentous, septate, anastomosing. Ascospores 2- (rarely 3-) celled, ellipsoidal, straight, ends rounded, slightly tapering to one end, first septum forms in the upper third of the ascospore, slightly constricted at first septum, second septum if present inconspicuous and thin-walled, second septum in the lower third of ascospore, not constricted, (27.5)28-32(33) $\times(14) 15-17(17.5) \mu \mathrm{m}(\mathrm{n}=30)$, brown to dark brown, wall up to $1 \mu \mathrm{m}$ thick, verrucose, germinating at distal or lateral part of lower cell (more rarely at upper cell) with a multicellular, conical, multilobate and dark brown appressorium from which surface mycelium is formed laterally, upper and lower cell of ascospore collapse during development of first appressorium. Anamorph not observed.

Known hosts: Annonaceae: Guatteria dolichopoda Donn. Sm. (Hansford, 1949), Guatteria sp. (Theissen, 1913), Oxandra venezuelana R.E. Fr. (new host plant genus and species) and Xylopia sp. (new host plant genus).

Known distribution: Neotropics: Central America - Costa Rica (Hansford, 1949), Panama (new record) and South America - Brazil (Spegazzini, 1889). A. nodulosa occurs in western Panama in lowland gallery forests at approx. $140 \mathrm{~m}$ a.s.l.

Specimens examined. COSTA RICA. Alajuela Province: San Pedro de San Ramon, 2 May 1925, H. Sydow 683 (BPI 690122, labeled as Asterina nodulosa). BRAZIL. Pernambuco: Recife, Dois Irmãos, on Xylopia sp., 16 March 1960, O. Soares 18841 (BPI 671071, labeled as Asterolibertia malpighii). PANAMA. Chiriquí Province: Los Algarrobos, border of Majagua river, ca. $140 \mathrm{~m}$, epiphyllous on Oxandra venezuelana (det. T.A. Hofmann), associated with various hyperparasites, 3 October 2005, T.A. Hofmann et al. 356 (FR, PMA); same locality, host species and associated organisms, 22 March 2006, T.A. Hofmann et al. ppMP 482 (M-0141024, PMA); same locality, host species and associated organisms, 11 June 2006, T.A. Hofmann 465 (FR, PMA); same locality, host species and associated organisms, 21 June 2006, T.A. Hofmann et al. ppMP 599 (M-0141025, PMA); same locality, host species and associated organisms, 10 January 2007, T.A. Hofmann el al. ppMP 1203 (M-0141026, PMA); same locality, host species and associated organisms, 8 September 2007, T.A. Hofmann 528 (PMA).

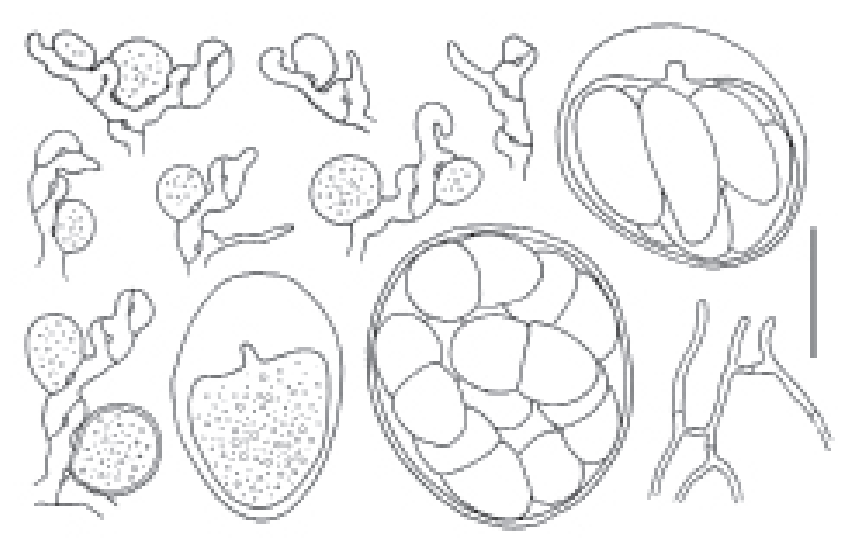

FIGURE 3 - Ascogenous hyphae, young asci and interascal tissue of Asterolibertia nodulosa (T.A. Hofmann et al. 356). Scale bar $=$ $20 \mu \mathrm{m}$. 

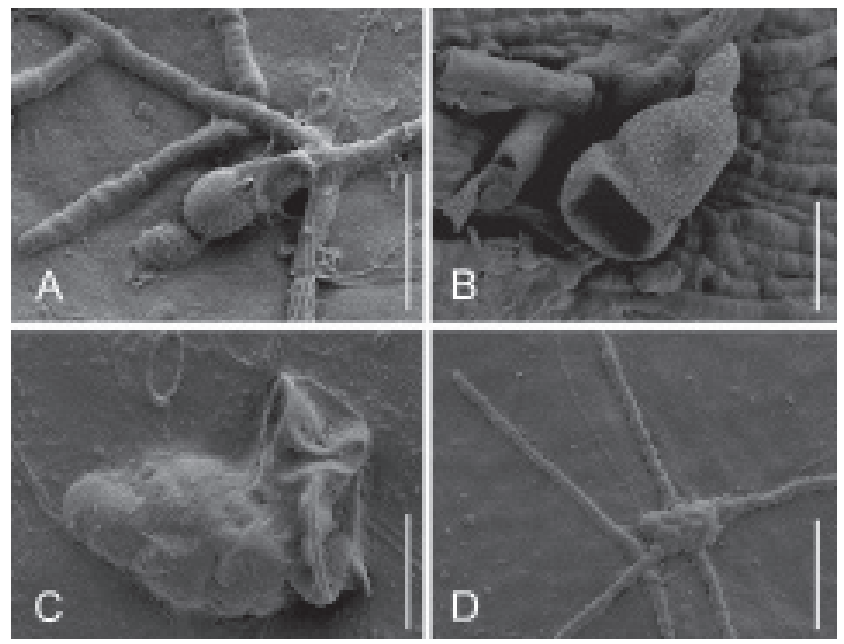

FIGURE 4 - SEM photographs of Asterolibertia spp. from Panama. A. Germinated, verrucose ascospore of Asterolibertia licaniicola on Licania arborea (T.A. Hofmann 578). Scale bar $=$ $30 \mu \mathrm{m}$; B-D. Asterolibertia nodulosa on Oxandra venezuelana (T.A. Hofmann et al. 356); B. Mature, collapsed ascospore. Scale bar $=15 \mu \mathrm{m} ; \mathbf{C}$. Collapsed ascospore (right) with primary, lobed appressorium (left). Scale bar $=15 \mu \mathrm{m}$; D. Lobed appressorium with surface mycelium. Scale bar $=40 \mu \mathrm{m}$.

Notes: Extended hypostromata below large colonies of Asterolibertia nodulosa can cause the local death of infected host tissue. The specimens on $O$. venezuelana from Panama are associated with various foliicolous fungi and numerous hyperparasites. The infection strategy, as well as ascus initials and conical appressoria developed by ascospores of $A$. nodulosa are illustrated here for the first time.

Asterina nodulosa Speg. was described by Spegazzini on Tabebuia sp. from Apiahy, Brazil (Spegazzini, 1889). Theissen (1912) examined the type material and considered the species as heterotypic synonym of Aina. inaequalis Mont. However, one year later he separated the taxon as a variety Aina. inaequalis var. nodulosa Theiss. due to smaller ascomata and ascospores (Theissen, 1913). The variety was not considered by later authors and Aina. nodulosa was treated a synonym of Aina. inaequalis (Toro, 1933; Müller \& Arx, 1962). Later Hansford (1949) recombined Aina. nodulosa into Asterolibertia nodulosa based on material collected by H. Sydow 1925 on Guatteria dolichopoda (Fungi exotici exsiccati 683) in Costa Rica. However, Hansford did not examine the type specimen of Aina. nodulosa from Brazil. We examined the Fungi exotici exsiccati 683 and this specimen is conspecific with the specimens from Panama. Unfortunately, we could not observe Spegazzini's type. It is possible that the type specimen from Brazil contains a fungus that differs from Sydow's specimen from Costa Rica. If this is the case, then A. nodulosa sensu Hansford (1949) is illegitimate. Batista \& Maia (1960) recombined A. nodulosa into Wardina nodulosa (Speg.) Bat. \& H. Maia based on the material from Costa Rica studied by Hansford 13 years earlier and without examining the type specimen from Brazil. Wardina is considered a synonym of Asterolibertia by Müller \& Arx (1962).

Cirsosia splendida Bat. \& H. Maia, Rev. Biol. 2:125 (1960). Figures 5, 7A-B

Type on Hirtella americana (Chrysobalanaceae). Brazil, Pernambuco, Recife, R.M. Rocha Batista s.n. (holotype, URM 2990 n.v.).

Anamorph: Homalopeltis chrysobalani (Henn.) Bat. \& Valle, IMUR 337:6 (1961), new anamorph - teleomorph connection. Figures 6, 7C-D.

Type on Chrysobalanus icaco L. (Chrysobalanaceae). Brazil, Pará, Belém, Botanical Garden Goeldi, 20 January 1908, C.F. Baker 244 (syntypes, B n.v., HBG n.v., MG 20408 n.v., BPI 391611!, S F40793 n.v., labeled as Leptothyrella chrysobalani)

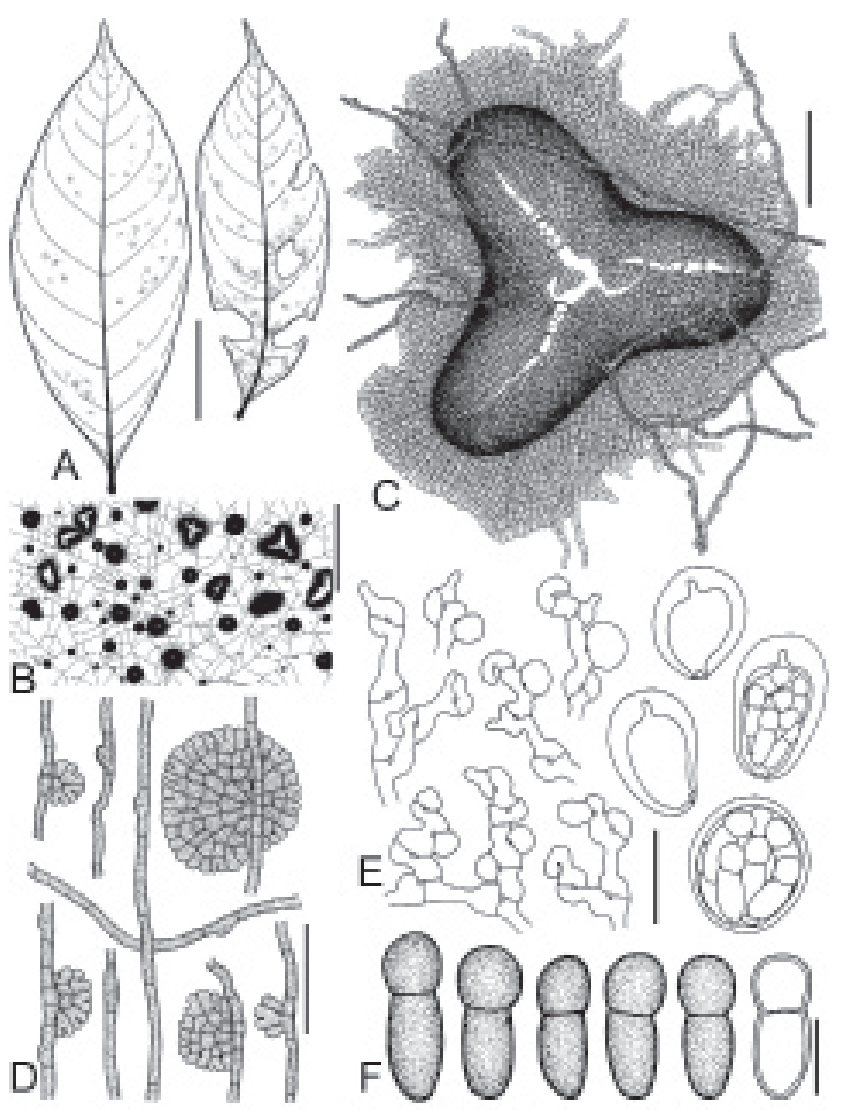

FIGURE 5 - Cirsosia splendida on Hirtella triandra (ppMP 1207). A. Infected leaves of Hirtella triandra. Scale bar $=2.5 \mathrm{~cm}$; B. Part of the colony with elongated thyriothecia, circular pycnothyria and surface mycelium. Scale bar $=600 \mu \mathrm{m} ; \mathrm{C}$. Y-shaped ascoma with central slits and surface mycelium. Scale bar $=50 \mu \mathrm{m}$; D. Surface mycelium with intercalary appressoria and ascoma initials. Scale bar $=30 \mu \mathrm{m}$; E. Young asci develop on ascogenous hyphae with proliferating croziers. Scale bar $=20 \mu \mathrm{m} ; \mathbf{F}$. Mature ascospores, ornamentation not shown. Scale bar $=10 \mu \mathrm{m}$. 


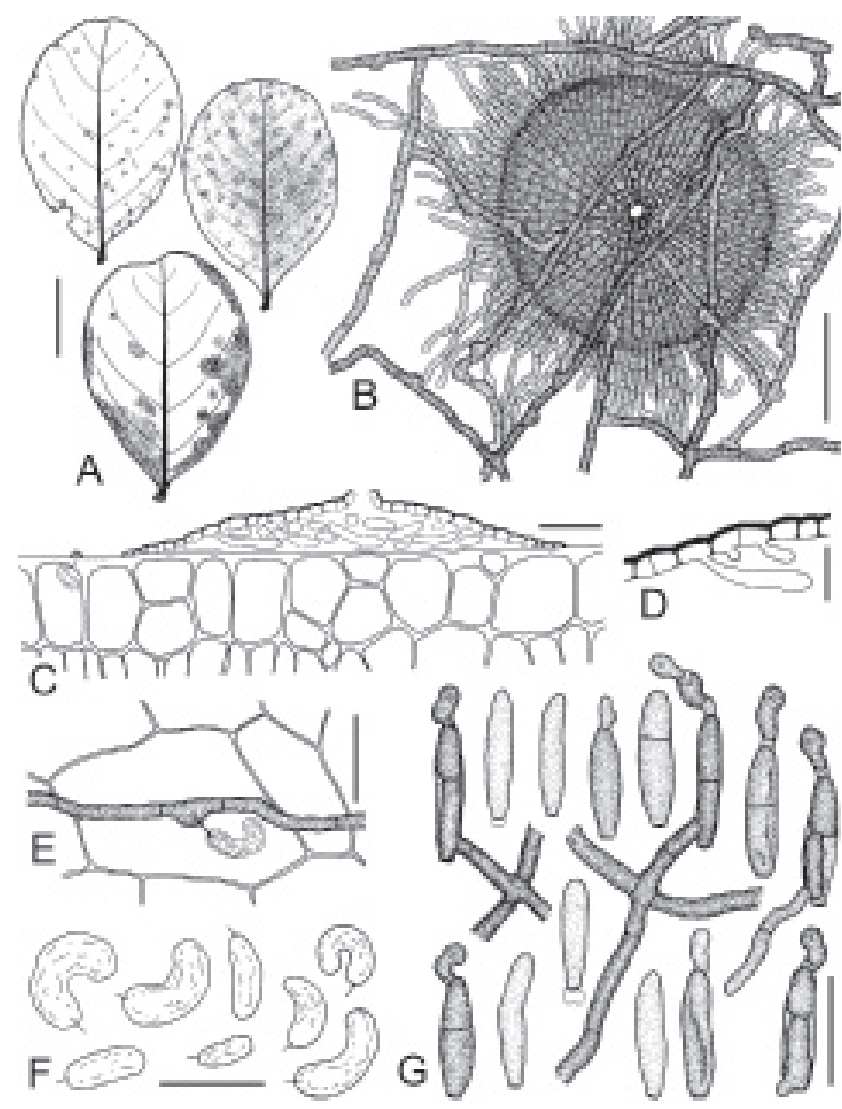

FIGURE 6 - Homalopeltis chrysobalani on Chrysobalanus icaco. A. Infected leaves (ppMP 1145). Scale bar $=2 \mathrm{~cm} ; \mathbf{B}$. Mature pycnothyrium with a central pore (M. Piepenbring \& R. Kirschner 3175). Scale bar $=40 \mu \mathrm{m}$; C. Cross section through a mature pycnothyrium and host tissue (ppMP 571). Scale bar $=$ $25 \mu \mathrm{m}$; D. Part of scutellum layer with conidiogenous cells and young conidia (ppMP 571). Scale bar $=10 \mu \mathrm{m}$; E. Haustorium in epidermal host cell (ppMP 1207). Scale bar $=15 \mu \mathrm{m}$; F. Shapes of haustoria (ppMP 1207). Scale bar $=15 \mu \mathrm{m} ;$ G. 1-celled, immature and 2-celled, mature conidia, some of them germinating. Lower cell of conidium collapses during germination and endohyphae develops (ppMP 1207). Scale bar $=20 \mu \mathrm{m}$.

\section{$\equiv$ Leptothyrella chrysobalani Henn., Hedwigia} 48:114 (1908).

= Leprieurina radiata Toro, Journ. Dept. Agric. Porto Rico 5:16 (1926). Type on Chrysobalanus icaco L. (Chrysobalanaceae). Puerto Rico. Loíza, 16 November 1925, R.A. Toro 428 (type, BPI 391581!), syn. nov.

Colonies amphigenous, irregularly circular, single, later becoming confluent, $0.5-4 \mathrm{~mm}(\mathrm{n}=10)$, conspicuous and dense on $C$. icaco, often covering large parts of leaves, very inconspicuous and discrete on $H$. triandra, black. Surface hyphae straight to undulating, branches mostly opposite, sometimes unilateral or alternate, brown to dark brown, at tips paler, septate, cells cylindrical, (5)11-22(32) $\times(2.5) 3-$ $5(5.5) \mu \mathrm{m}(\mathrm{n}=30)$, wall $0.5 \mu \mathrm{m}$ thick, smooth. Appressoria numerous, intercalary, cylindrical cell with a slightly swollen middle part on one side of hyphae, (8.5)10-13(15) $\times(4) 5$
6(7.5) $\mu \mathrm{m}(\mathrm{n}=60)$, penetration pore central, up to $1 \mu \mathrm{m}$ diam. Haustoria ellipsoidal, sausage-shaped, reniform or U-shaped, arbuscular, (11)12-16(17) ×5-6 $\mu \mathrm{m}(\mathrm{n}=10)$, hyaline, filling up to $1 / 5$ of host cell. Thyriothecia single or confluent, elongated, L-, Y- or X-shaped, dimidiate, fringed at margins, (150)227-544(600) $\times(110) 135-$ $368(500) \mu \mathrm{m}(\mathrm{n}=27)$, brown to dark brown, opening with central longitudinal slits. Scutellum radiate, composed of dichotomously branched filaments, cells isodiametric to cylindrical, straight in center, undulating at margins of ascoma, (3)4-7(10) $\times 2-5(6) \mu \mathrm{m}(\mathrm{n}=60)$, brown to dark brown. Asci globose to broadly clavate, or ovate, with ocular chambers, bitunicate, ascus walls I+, 22-27(28) $\mu \mathrm{m}$ diam. $(n=9), 8$-spored, developing on ascogenous hyphae with proliferating croziers, interascal tissue not observed. Ascospores 2-celled, ellipsoidal, elongated, straight or slightly bent, ends broadly rounded, lower cell sometimes acuminate and tapered to one end, septum in upper third of spore, constricted at septum, 18-21(22) $\mu \mathrm{m}$ long $(\mathrm{n}=11)$, upper cell 7-9(10) $\mu \mathrm{m}$ wide, lower cell (6)7-8 $\mu \mathrm{m}$ wide, pale brown to brown, cell wall up to $1 \mu \mathrm{m}$ thick, slightly verrucose, germinating ascospores not observed.

Anamorph present, called Homalopeltis chrysobalani. Pycnothyria numerous, single or confluent, circular, dimidiate, fringed at margins, (70)102-188(260) $\mu \mathrm{m}$ diam. $(\mathrm{n}=60)$, brown to dark brown, with central ostiole, (6)7-9(10) $\mu \mathrm{m}$ diam. $(\mathrm{n}=40)$. Conidiogenous cells monoblastic, formed by single cells of inner part of scutellum layer. Conidia numerous per pycnothyrium, first 1-celled, later becoming 2-celled, ellipsoidal, elongated,
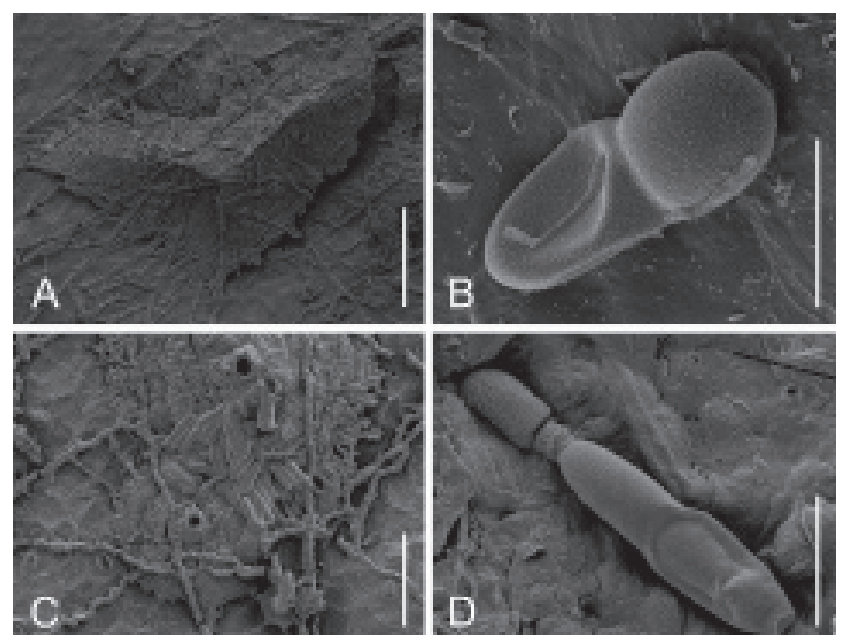

FIGURE 7 - SEM photographs of Cirsosia splendida and its anamorph Homalopeltis chrysobalani on Chrysobalanus icaco (Chrysobalanaceae) (ppMP 517). A, B. Teleomorph C. splendida. C, D. Anamorph $H$. chrysobalani. A. Elongated, L-shaped thyriothecium. Scale bar $=100 \mu \mathrm{m} ;$ B. Mature, verrucose ascospore. Scale bar $=10 \mu \mathrm{m}$; C. Two mature pycnothyria with central pores and masses of liberated conidia. Scale bar $=50 \mu \mathrm{m}$; D. Mature, germinating conidium with collapsed lower cell. Scale bar $=10 \mu \mathrm{m}$. 
upper end rounded or acuminate, lower end with truncate hilum, septum developing in the center or in the upper third of a mature conidium, not constricted, (19)21-24(25) $\times 4$ $7(8) \mu \mathrm{m}(\mathrm{n}=60)$, first hyaline, pale to dark brown when fully mature, smooth, hilum of hyaline conidia sometimes with mucous droplet, development of septum and pigmentation after spore discharge, germinating at distal part of upper cell with a stalked simple appressorium, lower cell collapsing during germination, after successful penetration of host by first appressorium upper cell forming endohyphae through collapsed lower cell to initiate growth of appressoriate surface mycelium.

Known hosts: teleomorph: Chrysobalanaceae Chrysobalanus icaco L. (new host plant species), Hirtella americana L. (Batista \& Maia, 1960) and H. triandra Sw. (new host plant species); anamorph: Chrysobalanaceae $-C$. icaco L. (Batista \& Valle, 1961; Toro, 1926 as Leprieurina radiata), $H$. americana $\mathrm{L}$. and $H$. triandra Sw. (new host plant genus and species).

Known distribution: Neotropics: Caribbean Puerto Rico (Toro, 1926, as Leprieurina radiata), Central America (new record) - Panama (new record) and South America - Brazil (Batista \& Maia, 1960; Batista \& Valle, 1961). Cirsosia splendida occurs in the anamorphic and teleomorph state in western Panama on the pacific coast, from 0 to about $5 \mathrm{~m}$ a.s.l., and in semi-deciduous lowland forests at approx. $150 \mathrm{~m}$ a.s.1.

Specimens examined: BRAZIL. Pará: syntype of $H$. chrysobalani, see above; same locality and host plant, 15 April 1908, C.F. Baker 244 (BPI 391607, BPI 391609, BPI 391610, BPI 391612, all labeled as L. chrysobalani); same locality and host plant, April, C.F. Baker, comm. H. Rehm (BPI 391605, BPI 391608, both labeled as L. chrysobalani). PANAMA. Chiriquí Province: La Barqueta, pacific coast, ca. 5 m a.s.l., amphigenous on Chrysobalanus icaco (det. M. Piepenbring), 19 February 2003, M. Piepenbring \& R. Kirschner 3175 (PMA); same locality and host plant, associated epiphyllous with a parasitic algae Cephaleuros cf. tumidae-setae Thompson \& Wujek (Trentepohliales), epiphyllous Plochmopeltis sp. (Schizothyriaceae) and hypophyllous Halbanina sp. (Asterinaceae) and other Micropeltidaceae, 18 October 2005, T.A. Hofmann, M. Piepenbring \& R. Mangelsdorff ppMP 422 (M-0141050, PMA); same locality, host species and associated organisms, 13 April 2006, T.A. Hofmann, M. Piepenbring \& T. Trampe ppMP 571 (M-0141051, PMA); same locality, host species and associated organisms, 11 July 2006, T.A. Hofmann, R. Mangelsdorff \& T. Trampe ppMP 1145 (M-0141052, PMA); same locality, host species and associated organisms, 22 January 2007, T.A. Hofmann, R. Mangelsdorff \& T. Trampe ppMP 1264 (M-0141053, PMA); same locality, host species and associated organisms, 6 September 2007, T.A. Hofmann 516 (FR, PMA); same locality, host species and associated organisms, 31 October 2007, T.A. Hofmann 604 (PMA); Los Algarrobos, border of Majagua river, ca. $140 \mathrm{~m}$ a.s.l. amphigenous on Hirtella triandra (det. T.A. Hofmann), associated amphigenous with Micropeltidaceae, 21 June 2006, T.A. Hofmann, R. Mangelsdorff \& T. Trampe ppMP 589 (M-0141054, PMA); same locality, host plant and associated organisms, 10 January 2007, T.A. Hofmann, R. Mangelsdorff \& T. Trampe ppMP 1207 (M-0141055, PMA). PUERTO RICO. Arecibo: Arecibo \& Lores Road, on H. triandra, 21 June 1915, F.L. Stevens 7303 (BPI 689911, BPI 689917, labeled as Asterina inaequalis var. nodulosa). Guanajibo: on C. icaco, 19 June 1915, F.L. Stevens 7203 (BPI 690403, labeled as Asterina schroeteri). Las Piedras: on C. icaco, 12 August 1915, F.L. Stevens 9323 (BPI 690405, labeled as A. schroeteri). Loíza: type of Leprieurina radiata, see above. Mayagüez: on C. icaco, 29 June 1915, F.L. Stevens 7413 (BPI 690401, BPI 690404, labeled as A. schroeteri). USA. Florida: Miami, intercepted at Miami 004783 Florida, 11 July 1973, M. Kuck (BPI 391606, labeled as A. schroeteri).

Notes: According to Batista \& Maia (1960), Cirsosia splendida grows intermixed with smaller, circular pycnothyria which form unicellular, bacilliform and hyaline conidia. A connection of the small conidia with the appressoriate surface mycelium of the teleomorph was not demonstrated by the authors. The small, bacilliform spores are probably formed by another fungus growing together with $C$. splendida. Unfortunately the type material of $C$. splendida could not be obtained from Brazil, although it was repeatedly requested.

The pycnothyria-forming fungus Homalopeltis chrysobalani was collected repeatedly on living leaves of Chrysobalanus icaco (Chrysobalanaceae) (Figure 6A) at the pacific coast of western Panama. H. chrysobalani forms brown surface mycelia with intercalary appressoria and was described as asexual plant parasitic fungus without sexual morph (Batista \& Valle, 1961; Hennings, 1908). In older and very dense colonies of $H$. chrysobalani we observed elongated, L- or Y-shaped thyriothecia containing asci with 2-celled, brown ascospores. The thyriothecia-forming fungus corresponds to Cirsosia splendida. Both sexual and asexual morphs are characterized by the same type of appressoriate surface mycelium with saucer-shaped haustoria. Colonies of $C$. splendida together with $H$. chrysobalani could be observed additionally on a different host plant species, Hirtella triandra (Chrysobalanaceae), at a different location in a gallery forest in western Panama. However, on $H$. triandra the parasite develops much smaller and inconspicuous colonies (Figure 5A), with a less dominant asexual morph.

In 1926, Toro described Leprieurina radiata Toro on $C$. icaco from Puerto Rico. The type material of $L$. radiata from BPI was examined and is identical with $H$. chrysobalani, the asexual morph of $C$. splendida. 
Both teleomorph and anamorph were illustrated before (Bastista \& Maia, 1960; Batista \& Valle, 1961; Toro, 1926), however, the surface composition of ascomata, pycnidia, conidia, and the ornamentation of the ascospores are illustrated here for the first time (Figures 5-7).

During the revision of species of Asterinaceae on Chrysobalanaceae, type specimens of Asterina nodulifera were investigated. The fungus presents a surface mycelium with intercalary appressoria, circular ascomata, and brown 2-celled ascospores and therefore corresponds to a species of Asterolibertia. A corresponding recombination is proposed. A complete description in english is given below.

\section{Asterolibertia nodulifera (Syd. \& P. Syd.) T.A. Hofmann, comb. nov.}

Basionym: Asterina nodulifera Syd. \& P. Syd., Philipp J. Sci. 9:180 (1914).

Type on Angelesia splendens Korth. (Chrysobalanaceae). Philippines, Palawan Province, Taytay, May 1913, Merill 8901 (lectotype, designated here, BPI 690120!); same locality, date, host plant and collector (isolectotypes, BPI 690121!, S F12426 n.v.).

Mycobank MB809692

Colonies amphigenous, irregularly circular, single, sometimes confluent, conspicuous and dense, black. Surface hyphae straight, rarely undulating, branches mostly opposite, rarely unilateral or alternate, brown to dark brown, at tips paler, septate, cells cylindrical, (11)13-25(35)×(4.5)5-6(7) $\mu \mathrm{m}(\mathrm{n}=30)$, wall $1 \mu \mathrm{m}$ thick, smooth. Appressoria numerous, intercalary, short cylindrical cell swollen to one or both sides of hyphae, (9)10-12(13) $\times(8) 9-11(12) \mu \mathrm{m}(\mathrm{n}=30)$, penetration pore central, $3 \mu \mathrm{m}$ diam., often with ca. $1 \mu \mathrm{m}$ broad rim. Haustoria not observed. Thyriothecia single or confluent, circular, dimidiate, fringed at margins, (320)332398(420) $\mu \mathrm{m}$ in diam. $(\mathrm{n}=17)$, dark brown, opening with central star-shaped fissures. Scutellum radiate, composed of dichotomously branched filaments, cells isodiametric to cylindrical, straight, slightly undulating at margins of ascoma, (4)6-15(23)×(3)4-6(7) $\mu \mathrm{m}(\mathrm{n}=30)$, brown to dark brown. Asci, ascogenous hyphae and interascal tissue not observed. Ascospores 2-celled, ellipsoidal, elongated, straight, ends broadly rounded, 33-35(36) $\times(13) 14-15 \mu \mathrm{m}$ $(n=16)$, septum in upper third of spore, upper cell globose, lower cell ellipsoidal and tapered, constricted at septum, brown, upper cell darker than basal cell, cell wall up to 1 $\mu \mathrm{m}$ thick, echinulate, germinating first at the distal part of the upper cell with a stalked, 1-celled appressorium, lower cell collapsing during germination. Anamorph not observed.

\section{DISCUSSION}

The family Asterinaceae requires substantial revision on morphological and molecular level. Many species are described without any illustration or detailed discussion of morphologically related species. Type material is often in bad condition or difficult to access. Data on host specificity are lacking, since these obligate biotrophic parasites cannot be cultivated (Hofmann \& Piepenbring, 2008, 2011). Field collection and detailed morphological analysis are necessary in order to understand the development and ecology of these apparently highly diverse tropical microfungi (Piepenbring et al., 2011). DNA sequences are not available for most of the representatives of the family, with exception of a few species of Asterina (Hofmann et al., 2010). Molecular analysis of Asterinaceae remains a challenging task due to the reduced hymenia and mostly melanized fungal structures, as well as the presence of other organisms on the same host plant. Dried voucher specimens are mostly not suitable for successful DNA extraction and fresh fungal material has to be accessed directly in the field. A representative sequence sampling of Asterinaceae is urgently needed to complete our understanding of the phylogenetic relationships in this poorly known lineage of Dothideomycetes.

\section{ACKNOWLEDGEMENTS}

We thank the German Research Foundation (DFG) for financial support of the project plant parasitic microfungi (ppMP), the German Academic Exchange Service (DAAD) for travel funds, and the Autoridad Nacional del Ambiente, Panama (ANAM) for granting collection and export permits. The Curators of BPI and PREM, are thanked for providing type specimens. Special thanks to R. Mangelsdorff and T. Trampe for assistance in the field, M. Ruppel for technical assistance with SEM and staff of INDICASAT for writing assistance and revision of English language. This study was supported by the National Secretariat of Science, Technology and Innovation (SENACYT, Panama) through the National Research System (SNI) and the LOEWE excellence initiative of the state of Hessen within the framework of the Cluster for Integrative Fungal Research (IPF).

\section{REFERENCES}

Arnaud G (1925) Lés Asterinées. IVe partie. Annals d'École National d'Agriculture de Montpellier, série 10 5:643-722.

Batista AC, Maia HS (1960) Cirsosia Arnaud e Cirsosina Bat. Novas species. Revista de Biologia 2:115-136.

Batista, AC, Valle C (1961) Homalopeltis e Plenotrichaius, novos gênero de fungos Peltasterales. Publicações Instituto de Micologia da Universidade de Recife \& Instituto Nacional de Pequisa 337:114.

Hansford GC (1946) The foliicolous ascomycetes their parasites and associated fungi. Mycological Papers 15:1-139.

Hansford GC (1949) Tropical fungi. III. New species and revisions. Proceedings of the Linnean Society London 160:116-153.

Hennings PC (1908) Fungi Paraënses III. Hedwigia 48:101-117.

Hofmann TA, Piepenbring M (2008) New species and records of Asterina from Panama. Mycological Progress 7:87-98. 
Hofmann TA, Piepenbring M (2011) Biodiversity of Asterina species on Neotropical host plants: new species and records from Panama. Mycologia 103:1284-1301.

Hofmann TA, Kirschner R, Piepenbring M (2010) Phylogenetic relationships and new records of Asterinaceae (Dothideomycetes) from Panama. Fungal Diversity 43:39-53.

Hosagoudar VB, Krishnan PN, Abraham TK (1997) Biochemical changes in the sandal tree infected with Asterina congesta Cooke. New Botanist 24:27-32.

Müller E, von Arx JA (1962) Die Gattungen der didymosporen Pyrenomyceten. Beiträge zur Kryptogamenflora der Schweiz 11:1-922.

Piepenbring M, Hofmann TA, Kirschner R, Mangelsdorff R, Perdomo O, Rodríguez Justavino D, Trampe T (2011) Diversity patterns of Neotropical plant parasitic microfungi. Ecotropica 17:27-40.
Spegazzini CL (1889) Fungi Puiggariani. Pugillus 1. Boletin de la Academia Nacional de Ciencias de Córdoba 11:381-622.

Sydow H, Sydow P (1914) Fungi from northern Palawan. Philippine Journal of Science 9:175-189.

Theissen F (1912) Fragmenta brasilica IV nebst Bemerkungen über einige andere Asterina-arten. Annales Mycologici 10:1-32.

Theissen F (1913) Die Gattung Asterina. Abhandlungen der Zoologisch-Botanischen Gesellschaft in Wien 7:1-130.

Toro RA (1926) Mycological notes I. Journal of the Department of Agriculture of Puerto Rico 10:11-23.

Toro RA (1933) Especies de Asterina Lév. en las Melastomáceas. Boletín de la Sociedad Española de Historia Natural 33:187-199.

Verbruggen N, Hermans C (2008) Proline accumulation in plants: a review. Amino acids 35:753-759.

Woodson RE Jr, Schery RW (Eds.) (1943-1980) Flora of Panama, 41 vols. St. Louis, MO, USA. Missouri Botanical Garden. 